\title{
Advances and the Application Value of Plant Copper Transporters
}

Sun Yanyu, Zhang Jinyu, Guo Donglin $\triangle$

College of Life Science and Technology, Harbin Normal University, The Molecular Genetics and Genetics Breeding Key Laboratory of Heilongjiang Provence, Harbin, 150025, China

$\triangleright$ Corresponding author email: gdl hsd@163.com

Plant Gene and Trait, 2020, Vol.11, No.8 doi: 10.5376/pgt.2020.11.0008

Received: 24 Jun., 2020

Accepted: 25 Jul., 2020

Published: 31 Aug., 2020

Copyright $\odot \mathbf{2 0 2 0}$ Sun et al., This article was first published in Molecular Plant Breeding in Chinese, and here was authorized to translate and publish the paper in English under the terms of Creative Commons Attribution License, which permits unrestricted use, distribution, and reproduction in any medium, provided the original work is properly cited.

Preferred citation for this article:

Sun Y.Y., Zhang J.Y., and Guo D.L., 2020, Advances and the application value of plant copper transporters, Plant Gene and Trait, 11(8): 1-12 (doi: $\underline{10.5376 / \text { pgt.2020.11.0008) }}$

\begin{abstract}
Copper pollution in soil leads to poor crop quality and low yield, which is a major problem in agricultural production. Plant copper transporters have functions of copper absorption, chelation, compartmentation and metabolic utilization, and participate in the regulation of copper homeostasis in plant. This review presumptively summarizes the gene expression characteristics, subcellular localization and the effecting of knockout or overexpression genes of plant copper transporters; emphatically illuminates the roles of plant copper transporters in copper uptake and root retention, long-distance transport, intracellular compartmentalization and accumulation in reproductive organs; and put forwards the research direction and prospect. The aim is to provide scientific theoretical basis for the screening and cultivation of copper-tolerant crops in order to prevent the potential threat of food safety in agricultural land with slight copper contamination, and help to establish efficient crop breeding mechanism and reasonable planting measures.
\end{abstract}

Keywords Plant; Copper contamination; Copper transporter

With the extensive use of pesticides, fungicides and wastewater irrigation in agriculture, copper contamination has become a major problem in sustainable agricultural production (Muhammad et al., 2015; Zhu et al., 2018). A survey in 2014 showed that the exceeding standard rate of copper contamination in China reached 2.1\% (Ministry of Environmental Protection, 2014). Copper pollution has high persistence and inhibits plant growth, resulting in crop yield reduction (Huang et al., 2016). Plants have a complex copper steady-state network, regulating the absorption and distribution of copper (Boutigny et al., 2014), and maintaining the normal growth of plants in a certain range of copper concentration soil. Plant accumulation and interaction with growth environment can be used to improve soil copper pollution. Studies have shown that plants tend to retain excessive copper in roots and stems, but not accumulate too much in seeds. Therefore, using crops to improve slight copper-contaminated soil is a feasible way to improve the harmful effects of copper pollution and meet the food demands of the intensively increasing population (Muhammad et al., 2015). However, high copper accumulation in food and feed edible parts poses a threat to human and animal health (Kulhari et al., 2013). Food safety must be guaranteed. Therefore, it is necessary to understand the absorption mechanism of copper by plants, as well as to understand the distribution characteristics of copper in plants, and to achieve the dual purpose of reasonable improvement of copper-contaminated soil and food production safety.

In recent years, there have been a lot of reports on the toxicity level, physiological and biochemical effects, and damage mechanism of copper to plants. The tolerance of plants to copper toxicity is closely related to the absorption and transfer of copper. As an important part of plant copper homeostasis regulation system, plant copper transporters have functions of copper absorption, chelation, compartmentation, and metabolic utilization, and are key factors affecting copper stress tolerance, copper removal efficiency and copper distribution in plants. Plant copper transporters have been paid more and more attention, but there is a lack of systematic research reports. This review summarizes latest research progress of plant copper transporters, which provides a theoretical basis for deepening the understanding of plant copper homeostasis and improving crop breeding of copper-contaminated soil. 


\section{Characteristics of Plant Copper Transporters}

Plant transporters with the ability of copper transporter include plant copper transporter (COPT), heavy metal transporting ATPase (HMA), yellow stripe like (YSL), Zinc/Iron regulated transporters (ZIP) and other family proteins. COPT has abundant functions, such as participating in copper uptake, copper distribution in overground tissues, re-circulation of intracellular copper storage and pollen development (Sancenón et al., 2004; Dumay et al., 2006; Carrio-Segui et al., 2015). The COPT characteristics related to copper transport have been proved as follows. Studies have shown that the expression of copper transporter gene has tissue specificity and copper induction characteristics. In general, these copper transporters are expressed in different plant tissues, such as AtCOPT1/2/5 and AtYSL2 in Arabidopsis thaliana. Some transporters have high tissue specificity. Among the studied copper transporters, most of the COPT family proteins are expressed in roots and reproductive tissues. For example, AtCOPT1/5, MtCOPT1/4/5/, VvCTr1, TaCT1 are expressed in roots. And MtCOPT3 has nodule specificity. AtCOPT1/3/5/6 are expressed in reproductive tissues, AtCOPT1/5/6 are particularly abundant in pollen, AtCOPT5 is expressed in nuts, TaCT1 is expressed in spikelets. And a small amount of COPT such as AtCOPT6, $M t C O P T 8$ and $V v C T r 1$ are expressed in stems and leaves (Table 1; Table 2; Table 3).

Table 1 The characteristics of known COPT associated with copper transport in plant

\begin{tabular}{|c|c|c|c|c|c|}
\hline Species & Gene & Express parts & Induced expression & Subcellular localization & Reference \\
\hline \multirow[t]{5}{*}{$\begin{array}{l}\text { Arabidopisis } \\
\text { thaliana }\end{array}$} & AtCOPT1 & $\begin{array}{l}\text { Most tissues, roots, } \\
\text { pollen, reproductive } \\
\text { tissue }\end{array}$ & High copper down & Plasma membrane & $\begin{array}{l}\text { Amparo et al., } 2018 \\
\text { Senovilla et al., } 2018\end{array}$ \\
\hline & $A t C O P T 2$ & Most tissues & High copper down & Plasma membrane & $\begin{array}{l}\text { Amparo et al., } 2018 \\
\text { Senovilla et al., } 2018 \\
\text { Garcia-Molina et al., } 2013\end{array}$ \\
\hline & AtCOPT3 & Reproductive tissue & - & $\begin{array}{l}\text { Chamber of secretory } \\
\text { pathway }\end{array}$ & Amparo et al., 2018 \\
\hline & AtCOPT5 & $\begin{array}{l}\text { Most tissues, roots, } \\
\text { reproductive tissues, } \\
\text { pollen, and nuts }\end{array}$ & - & Vacuole & $\begin{array}{l}\text { Amparo et al., } 2018 \\
\text { Garcia-Molina et al., } 2013 \\
\text { Klaumann et al., } 2011\end{array}$ \\
\hline & AtCOPT6 & $\begin{array}{l}\text { Reproductive tissue, } \\
\text { xylem and phloem } \\
\text { vascular tissue }\end{array}$ & High copper up & Plasma membrane & $\begin{array}{l}\text { Amparo et al., 2018; } \\
\text { Garcia-Molina et al., } 2013 \\
\text { Jung et al., } 2012\end{array}$ \\
\hline $\begin{array}{l}\text { Brassica } \\
\text { napus }\end{array}$ & $B n C O P T 2$ & Roots & $\begin{array}{l}\text { Up in copper } \\
\text { deficient roots }\end{array}$ & - & Billard et al., 2014 \\
\hline Medicago & $\mathrm{MtCOPT1}$ & Roots & - & Plasma membrane & Senovilla et al., 2018 \\
\hline \multirow[t]{3}{*}{ truncatula } & МtCOРT3 & Nodules & - & - & Senovilla et al., 2018 \\
\hline & $M t C O P T 4 / 5$ & Roots & - & - & Senovilla et al., 2018 \\
\hline & MtCOPT8 & $\begin{array}{l}\text { Roots, xylem and } \\
\text { phloem vascular tissue }\end{array}$ & - & - & Senovilla et al., 2018 \\
\hline $\begin{array}{l}\text { Triticum } \\
\text { aestivum }\end{array}$ & TaCT1 & $\begin{array}{l}\text { Xylem and phloem } \\
\text { vascular tissue, roots, } \\
\text { spikelets }\end{array}$ & High copper down & Golgi apparatus & Li et al., 2013 \\
\hline \multirow[t]{2}{*}{ Vitis vinifera } & $V v C \operatorname{Tr} 1$ & $\begin{array}{l}\text { Xylem and phloem } \\
\text { vascular tissue, leaf, } \\
\text { roots }\end{array}$ & Deficient copper up & Tonoplast & Leng et al., 2015 \\
\hline & $V v C \operatorname{Tr} 2 / 8$ & - & High copper up & - & Martins et al., 2014 \\
\hline
\end{tabular}

HMA drives the transmembrane transport of heavy metal ions by hydrolyzing ATP, which is responsible for copper efflux, transport (Mills et al., 2005). HvHMA1, GmHMA8, and AtHMA5 are expressed in roots and flower, HvHMAl is expressed in seeds (Table 2). 
Plant Gene and Trait 2020, Vol.11, No.8, 1-12

http://genbreedpublisher.com/index.php/pgt

Table 2 The characteristics of known HMA associated with copper transport in plant

\begin{tabular}{|c|c|c|c|c|c|}
\hline Species & Gene & Express parts & $\begin{array}{l}\text { Induced } \\
\text { expression }\end{array}$ & $\begin{array}{l}\text { Subcellular } \\
\text { localization }\end{array}$ & Reference \\
\hline \multirow[t]{4}{*}{ Arabidopisis thaliana } & AtHMA1 & Green organization & - & Chloroplast envelope & Boutigny et al., 2014 \\
\hline & AtHMA5 & Roots, flower & High copper up & Plasma membrane & Patterson et al., 2006 \\
\hline & AtHMA6 & Roots, shoots & - & Chloroplast & Catty et al., 2011 \\
\hline & AtHMA 8 & Overground part & $\begin{array}{l}\text { High copper } \\
\text { degradation }\end{array}$ & Thylakoid membrane & $\begin{array}{l}\text { Gayomba et al., } 2013 \\
\text { Zhang et al., } 2018 \\
\text { Tapken et al.,2012 }\end{array}$ \\
\hline \multirow[t]{2}{*}{ Oryza sativa } & OsHMA5 & $\begin{array}{l}\text { Root column sheath cell, the } \\
\text { xylem area of the vascular } \\
\text { bundle at the node, pedicel, } \\
\text { petiole, vascular tissue of } \\
\text { fruit shell }\end{array}$ & High copper up & Plasma membrane & $\begin{array}{l}\text { Patterson et al., } 2006 \\
\text { Deng et al., } 2013\end{array}$ \\
\hline & OsHMA9 & $\begin{array}{l}\text { Xylem and phloem vascular } \\
\text { tissue }\end{array}$ & High copper up & Plasma membrane & $\begin{array}{l}\text { Lee et al., } 2007 \\
\text { Patterson et al., } 2006 \\
\text { Deng et al., } 2013\end{array}$ \\
\hline Brassica napus & BnHMA1 & Leaf & $\begin{array}{l}\text { Up in copper } \\
\text { deficient leaf }\end{array}$ & - & Billard et al., 2014 \\
\hline Glycine $\max$ & GmHMA8 & Leaf & - & Thylakoid membrane & Bernal et al., 2007 \\
\hline Hordeum vulgare & $H v H M A 1$ & Leaf, seeds & $\begin{array}{l}\text { High copper } \\
\text { down }\end{array}$ & $\begin{array}{l}\text { Chloroplast } \\
\text { envelope, the cell } \\
\text { cavity of grain } \\
\text { aleurone }\end{array}$ & Mikkelsen et al., 2012 \\
\hline Vitis vinifera & $V v P A A 1$ & - & $\begin{array}{l}\text { High copper } \\
\text { down }\end{array}$ & - & Martins et al., 2014 \\
\hline
\end{tabular}

YSL transports copper ions chelated by nicotinamide (NA) and plays a role in long-distance transport of copper (Waters et al., 2006). AtYSL2/3 and HvYSL2 are expressed in roots, stems and leaves (Table 3).

Table 3 The characteristics of known YSL associated with copper transport in plant

\begin{tabular}{|c|c|c|c|c|c|}
\hline Species & Gene & Express parts & $\begin{array}{l}\text { Induced } \\
\text { expression }\end{array}$ & $\begin{array}{l}\text { Subcellular } \\
\text { localization }\end{array}$ & Reference \\
\hline \multirow[t]{3}{*}{ Arabidopisis thaliana } & AtYSL1 & Most tissues, roots & $\begin{array}{l}\text { High copper } \\
\text { down }\end{array}$ & Plasma membrane & $\begin{array}{l}\text { Waters et al., } 2006 \\
\text { Chu et al., } 2010\end{array}$ \\
\hline & AtYSL2 & Most tissues, roots, stems & $\begin{array}{l}\text { High copper } \\
\text { down }\end{array}$ & $\begin{array}{l}\text { Plasma } \\
\text { membrane, } \\
\text { periphery of } \\
\text { vessel } \\
\text { parenchyma cell }\end{array}$ & $\begin{array}{l}\text { Didonato et al., } 2004 \\
\text { Garcia-Molina et al., } 2013\end{array}$ \\
\hline & AtYSL3 & Young leaves, stems, roots & $\begin{array}{l}\text { High copper } \\
\text { down }\end{array}$ & Plasma membrane & $\begin{array}{l}\text { Waters et al., } 2006 \\
\text { Chu et al., } 2010 \\
\text { Amparo et al., } 2018\end{array}$ \\
\hline Oryza sativa & OsYSL16 & $\begin{array}{l}\text { Roots, stems, phloem and } \\
\text { vascular tissue of leaves }\end{array}$ & $\begin{array}{l}\text { Up in copper } \\
\text { deficient stems }\end{array}$ & Plasma membrane & Zheng et al., 2012 \\
\hline \multirow[t]{2}{*}{ Arachis hypogaea } & AhYSL3.1 & $\begin{array}{l}\text { Roots, stems, young leaves, } \\
\text { and old leaf }\end{array}$ & $\begin{array}{l}\text { High copper up; } \\
\text { up in copper } \\
\text { deficient roots }\end{array}$ & Plasma membrane & Dai et al., 2018 \\
\hline & AhYSL 3.2 & $\begin{array}{l}\text { Roots, stems, young leaves, } \\
\text { old leaf, lateral root, taproot }\end{array}$ & $\begin{array}{l}\text { Up in copper } \\
\text { deficient roots }\end{array}$ & - & Dai et al., 2018 \\
\hline Hordeum vulgare & HvYSL2 & $\begin{array}{l}\text { Stems, young leaves, root } \\
\text { endoderm }\end{array}$ & $\begin{array}{l}\text { Up in copper } \\
\text { deficient leaf }\end{array}$ & - & Araki et al., 2011 \\
\hline
\end{tabular}

Tissue expression of copper transporters reflects their functional regions. COPT family proteins expressed in roots are closely related to copper absorption. YSL family proteins play a role in copper absorption and long-distance transport. COPT and HMA family proteins play an important role in reproductive tissues. And ZIP also participates in the copper homeostasis and transport of roots (Stephens et al., 2011). 
The expression of these family proteins is significantly affected by copper status in plants. Under copper deficiency, the expression of AhYSL3.1/3.2 and BnCOPT2 in roots, OsZIP12/4 and VvZIP4 in roots and stems, and BnHMA1 and HvYSL2 in leaves is up-regulated. While the expression of AtCOPT1/2, TaCT1, AtYSL2, $V v Z I P 2, V v P A A 1, M t Z I P 1 / 5 / 6$ and HvHMA1 is down-regulated, and AtHMA8 is degraded under high copper. High copper induced the expression of AtHMA5, VvCTr1/2/8, VvZIP4, AhYSL3.1, OsHMA5/9 up. The up-regulated genes in roots under copper deficiency can improve the ability of copper absorption, and the up-regulated genes in stems and leaves may mobilize copper in plants to transport copper from the storage part to the parts where life activities are more needed, to compensate for the possible loss of activity and reduce the effects of copper deficiency. When copper is high, most of the copper transport genes are down-regulated, indicating that the feedback inhibition of copper absorption, while the up-regulated transport genes such as $H M A$ may transfer and store excess copper to achieve the purpose of detoxification. The expression of copper transporter gene is regulated by regulatory network. Studies have shown that plant $S P L 7$ transcription factor is a key regulator of copper response genes. In Arabidopsis spl7 mutants, transporter genes such as COPT1, COPT2, ZIP2, YSL2, FRO3, as well as some transcription factors are mistakenly regulated. The $s p l 7$ mutant showed strong growth phenotype in low copper environment (Gayomba et al., 2013). OsATX1 interacts with heavy metals P1B-ATPases HMA4, HMA5, HMA6 and HMA9 in rice (Oryza sativa). OsATX1 may transport and distribute copper by transferring copper to HMA, so as to maintain copper homeostasis in different rice tissues (Zhang et al., 2018).

\subsection{Effects of knockout or overexpression of copper transporters on plants}

The overexpression of heterologous copper transporters can improve the ability of the copper absorption in plants (Singh et al., 2011), and affect the copper homeostasis of plants. Plants overexpressing COPT1 or COPT3 showed increased endogenous copper levels, but the expression and survival of circadian-related genes is compromised (Andrés-Colás et al., 2010). The roots of rice overexpressing AtCOPT1 were shortened under high copper and iron deficiency conditions, and the iron homeostasis was significantly affected (Andrés-Bordería et al., 2017). The root copper concentration of OSATXI overexpression rice decreased, but the copper accumulation in reproductive tissues and old leaves increased (Singleton and Brun, 2007). Under the condition of copper deficiency, the root growth damage of Atcopt 5 mutant seedlings stably transformed by $V v C T r 1$ was completely repaired, which supported the view that VvCTr1 was involved in intracellular copper transport (Martins et al., 2014). COPT5 played a certain role in the transfer of copper from roots to other tissues, and the root copper concentration of AtCOPT5 insertion mutant decreased (Carrio-Segui et al., 2015). OsHMA9-1 and OsHMA9-2 mutants showed increased sensitivity to elevated copper levels, supporting the view that $O S H M A 9$ plays a role in cell copper efflux (Lee et al., 2007). Above results confirm that these transporters are of great significance for copper homeostasis and other metal homeostasis in plants.

\subsection{Subcellular localization of copper transporter}

As transporters, COPT, HMA, YSL, ZIP and other copper transporters are mostly located in the membrane system of cells. Some COPT proteins are active in the plasma membrane, others are active in the intracellular membrane, such as the tonoplast, which is involved in copper entry and exit. AtCOPT2/6, MtCOPT1, OsHMA5, AtYSL2, AhYSL3.1, OsZIP1 are in plasma membrane. AtHMA6 is in chloroplast, AtHMA1 and HvHMA1 are in chloroplast envelope, AtHMA8 and GmHMA8 are in thylakoid membrane with small clusters and uneven distribution. AtCOPT5 is in copper storage organelle-vacuole, $\mathrm{VvCTr} 1$ trans-Golgi network is in the tonoplast through the anterior vacuole cavity, TaCT1 is in the Golgi apparatus. OsZIP1 is in endoplasmic reticulum. HvHMA1 is in the cell cavity of grain aleurone. AtCOPT3 is in a chamber of secretory pathway, and AtYSL2 is in the periphery of the highly vacuolar vessel parenchyma cell, which is difficult to distinguish the specific location on the two layers of the membrane. Subcellular localization is an important verification part of protein function. According to these localizations, copper transporters are in the plasma membrane or important organelle membrane and play an important role in intracellular copper exchange. 


\section{Plant Copper Transporter and Copper Absorption and Transfer}

\subsection{Role of copper transporters in root copper absorption and retention}

Plants rely on their roots to get copper from the soil. Sunflower (Helianthus annuus) (Yeh et al., 2015), radish (Raphanus sativus) (Hladun et al., 2015) and perennial peanut (Arachis hypogaea) have high copper bioaccumulation capacity. High affinity COPT could mediate copper absorption in roots. And AtCOPT1/2 and ZmCOPT1/2 could absorb $\mathrm{Cu}^{+}$. While Atcopt 1 inhibited copper absorption (Sancenón et al., 2004). COPT2 played a role in obtaining and distributing copper in the case of copper deficiency. Rice OsCOPT2/3/4 mediated high affinity copper uptake with OsCOPT6, while OsCOPT7 exerted copper uptake function alone (Yuan et al., 2011). $\mathrm{ZmCOPT} 3$ had low affinity copper (Wang et al., 2018). COPT protein transported $\mathrm{Cu}^{+}$, but the most available form of copper in soil was $\mathrm{Cu}^{2+}$. Therefore, copper reduction may promote the absorption of root cells. FRO protein in Arabidopsis thaliana absorbs reduced soil iron in plant roots. And copper deficiency also induced the expression of FRO3. FRO may also participate in the reduction and absorption of copper. It was also found that AtYSL2 in Arabidopsis thalian uptake copper chelated by NA in roots (Didonato et al., 2004). The copper absorption efficiency of plants depends on soil characteristics and copper bioavailability, as well as these transporters on the plasma membrane of plants.

After plants were given high copper, the copper content in roots increased significantly, but the copper content in stems did not increase at the early stage of stress, which indicates that copper is mainly accumulated underground after absorption (Desjardins et al., 2016). The results showed that maize (Zea mays) (Kacálková et al., 2009), rice (Oryza sativa) (Thounaojam et al., 2012), wheat (Triticum aestivum) (Mahmud et al., 2013), perennial ryegrass (Lolium perenne L.) (Chen et al., 2017), alfalfa (Medicago sativa) (Wang et al., 2006), ramie (Boehmeria nivea L.). (Rehman et al., 2019) and mustard (Brassica juncea) (Motior et al., 2013) had the ability of $\mathrm{Cu}$ accumulation in roots. Leaf is a photosynthetic tissue with high metabolic activity, which prevents the transfer of copper to leaves. It is an effective copper tolerance mechanism, which is related to gene expression and root secretion. Apple (Malus pumila) with different copper fixation ability showed transcriptional specificity of copper absorption and transport genes. Apple rootstocks with strong copper fixation ability retained more copper in the root cell wall and subcellular partition (Wan et al., 2019) by regulating the expression of copper transport genes. The copper tolerance of alfalfa was related to the secretion of organic acids and cell wall structure. The increase of copper concentration had little effect on the biomass of roots, stems and leaves of alfalfa. The increase of organic acid content in roots and cation exchange capacity of cell wall prevented the transport of copper to the overground part, and effectively protected the overground tissue (Wang et al., 2006).

\subsection{Plant copper transporters participate in long-distance copper transport in vivo}

The plant stem plays a central role in transferring and distributing minerals, water and other solutes (Printz et al., 2013). In order to maintain the copper content required for participating in life activities, copper should be transferred from roots to stems. Before entering the xylem, copper should be discharged from the root symbionts, transported to the xylem through parenchyma and endodermal cells, and brought to the mature leaves through transpiration, loaded to the phloem, and reached the new leaves, flowers and seeds. Studies have shown that the copper concentration in the overground part of some plants is higher than that in the underground part, for example, the copper concentration in sunflower seedlings is $2 \sim 4$ times higher than that in roots (Rahman et al., 2013). The copper content and accumulation in the overground of rice seedlings increased with the increase of copper supply, but the that in root did not increase with exogenous copper ( $\mathrm{Si}$ et al., 2007). Helianthus annuus, Raphanus sativus and Apium graveolens have higher ability to transfer copper from roots to stems (Yeh et al., 2015; Hladun et al., 2015; Li et al., 2019). There are great differences in rhizome transfer ability of copper in different species or in the same species. The potential of copper absorption and copper transport in lettuce (Lactuca sativa L.) is higher than that in spinach (Spinacia oleracea L.). And the copper of lettuce root is higher than that of stem, $60 \% \sim 80 \%$ of copper is stored in roots, but there is no significant difference in copper in spinach roots to stems (Ayari et al., 2010). In another study, the $\mathrm{Cu}^{2+}$ accumulation in roots of spinach seedlings was lower than that in overground parts (Gong et al., 2019). The results showed that there was more copper accumulation in the roots of Boehmeria nivea, followed by leaves and stems, but the copper accumulation in stems was the highest in Diyarbakir (Cevher-Keskin et al., 2018). 
Consistent with the role of xylem loading, the derivation of copper from cells is necessary for high copper tolerance and long-distance transport. HMA5 plays an important role in copper compartmentation and copper detoxification in roots. AtHMA5, OsHMA5 and OsHMA9 may be involved in copper efflux. Mutant studies verified its copper transport capacity from roots to stems. AtHMA5 knockout or conserved region mutations resulted in increased sensitivity to high copper and copper accumulation in rhizomes, while mutants showed copper sensitivity and decreased copper transport capacity (Kobayashi et al., 2008). Knockout of OsHMA5 resulted in the decrease of copper content in xylem sap of rice mutant, while the increase of copper concentration in root (Tapken et al., 2012). The root tip of OsHMA9 mutant accumulated copper (Lee et al., 2007). Despite the above experimental evidence, the specific mechanism of copper ion transport in xylem and phloem is not clear, and there is a lack of direct evidence. YSL transports copper ions chelated by nicotinamide (NA) with high affinity in xylem and phloem. Tomato NA accumulated too much copper due to lack of mutants, and the copper transport in xylem was greatly reduced. The addition of exogenous NA could restore the copper level in xylem and support the role of NA in xylem copper transport. AtYSL1/2/3 (Didonato et al., 2004; Amparo et al., 2018), HvYSL2 (Araki et al., 2011) could transport $\mathrm{Cu}^{2+}$-NA. OsYSL16 transported $\mathrm{Cu}-\mathrm{NA}$ to young tissue through phloem and knocked out OSYSL16. The copper concentration in old leaves was higher than that in young leaves (Zheng et al., 2012). When copper was excessive, the high expression of peanut AhYSL3.1 gene led to the decrease of copper level in young leaves of tobacco and rice (Dai et al., 2018). Medicago sativa has a potential remediation effect on copper-contaminated soil (Zhu et al., 2018). In this study, MsYSL6 gene was cloned from Medicago sativa. After soaking seeds for $7 \mathrm{~d}$ under $6 \mu \mathrm{M}$ copper stress, it was found that the average germination rate of tobacco seeds of MsYSL6 overexpression was 44\% higher than that of wild type and showed better growth state. After $15 \mathrm{~d}$, it was found that the average root length was $43 \%$ longer than that of wild type, and the average fresh weight was more than 39\%. It is suggested that MsYSL6 may be involved in copper transport in plants and can improve the tolerance of plants to copper stress, and its specific transport mechanism needs to be further studied.

Copper is not easily redistributed from old leaves to young leaves and meristem. Therefore, young leaves and stems are more susceptible to nutritional deficiency than mature leaves. The copper accumulation in the old leaves of Brassica napus was higher than that in young leaves (Khurana et al., 2006). However, studies also showed that copper deficiency reduced the growth rate of Brassica napus by less than 19\%, while the copper content in the old leaves decreased by $61.4 \%$, indicating that there was a copper reflow process between leaves.

\subsection{Copper transporters and intracellular compartmentalization}

After entering the leaf cells, copper ions are distributed in different organelles compartmentally. Copper is mainly distributed in the cell wall and cytosol in maize cells, and the copper content in the organelles such as nucleus, chloroplast and mitochondria are low. With the increase of copper concentration, the distribution of copper to cell wall decreased and to cytosol increased. The copper content was the highest in the cytosol of stem, followed by the cell wall (Si et al., 2008), and the copper content in the cell wall of leaf was the highest. Black dots distributed in vacuoles and cell walls of spinach leaves under high copper stress, which might be $\mathrm{Cu}^{2+}$ accumulation (Cevher-Keskin et al., 2018). Copper is distributed in vacuoles and cytoplasm containing a large number of chelates, which can reduce toxicity. On the other hand, vacuoles may be a transport pathway in cells. After metal ions are transported to the cytoplasm through vacuoles, they may encounter copper transporters only at a short distance of diffusion.

At high copper concentration, part of copper is transferred to the stroma $\mathrm{Cu} / \mathrm{Zn}$ superoxide dismutase mediated by AtHMA6 and copper chaperone protein CCS, and part of copper is transferred to AtHMA6(PAA1) on the inner membrane of chloroplast through the copper chaperone protein AtPCH1. AtHMA6 transports copper into the chloroplast stroma through the chloroplast envelope (Catty et al., 2011; Boutigny et al., 2014), and then AtHMA8(PAA2) transports copper to plastocyanin in the thylakoid lumen for normal photosynthesis (Tapken et al., 2012). Arabidopsis AtHMA1 participates in copper homeostasis in chloroplasts (Boutigny et al., 2014). When cells are copper deficient, HvHMA1 mobilizes copper in chloroplasts to be excreted to the cytoplasm (Mikkelsen 
et al., 2012). The interaction between AtHMA5 and copper chaperone ATX1-like plays a role in the compartmentation and detoxification of copper (Zhang et al., 2018). AtHMA5 may obtain copper from cytoplasmic copper chaperone. AtHMA7 transports copper to the Golgi apparatus and transmits copper as a co-factor through the endoplasmic reticulum to ethylene receptor located in the endoplasmic reticulum, which participates in the biological process of ethylene receptor (Chen et al., 2002). AtCOPT5 promotes the efflux of copper from vacuoles when copper is deficient. The copper content of Atcopt5 knockout vacuole is $1.5 \sim 1.8$ times higher than that of normal, which showed a strong defect of photosynthetic electron transport of plastocyanin (Klaumann et al., 2011). Under high copper stress, rice OsZIP1 knockout inhibited rice growth, while overexpression promoted rice growth. The dual localization of endoplasmic reticulum and plasma membrane also suggested that OsZIP1, as a metal efflux protein under excessive copper stress, may play a role in changing environmental conditions (Liu et al., 2019).

\subsection{Plant copper transporters and copper accumulation in reproductive organs}

Copper is required for plant flowering and seed maturation. Most of the copper in the reproductive tissue of Arabidopsis thaliana enters directly from the root through the vessel system, while others may be mobilized by the nutrient tissue vessel system through the phloem. Selective transfer of copper in seeds or grains may be the result of selective absorption of copper by vascular transport cells in plant reproductive tissues. Due to low transport efficiency, crop grains usually maintain normal copper levels (Kubota et al., 1992). Even if copper was added, the increase of copper in maize grains was still lower than that in leaves and stems. However, copper treatment increased the absorption of copper in various parts of radish, copper was evenly distributed and accumulated in roots, stems, leaves, flowers and seeds of radish (Hladun et al., 2015). The concentration of copper in soybean (Glycine max) seeds was higher than that in leaves and stems (Reddy et al., 1989). The copper accumulation in edible parts of crops grown on high copper soil needs to be closely monitored. Even for forage crops or ornamental plants, leaves and flowers may be foraging by herbivores and pollinators, so there is still a potential threat.

The copper content in flowers and seeds of AtYSL2 and AtYSL3 mutants was lower, but higher in rosette leaves and stems (Didonato et al., 2004). COPT5 transferred $\mathrm{Cu}$ from root to reproductive tissue (Klaumann et al., 2011), the pollen of Atcopt1 inhibition line was dysplastic, and the content of copper in pod and seed decreased (Sancenón et al., 2004). Under the condition of copper deficiency, the copper content in rosette leaves of Atcopt6 mutant increased, and the copper content in seeds decreased. Reintroduction of AtCOPT6 could save this phenotype (Garcia-Molina et al., 2013; Martins et al., 2014). OsHMA5 is a copper transporter in the xylem at the reproductive stage. The grain copper concentration of OSHMA5 knockout mutant is significantly lower than that of wild type, and the yield is also very low (Tapken et al., 2012). OsYSL16 transports copper to seeds through the phloem. Knockout of OsYSL16 resulted in higher copper concentrations in boot leaves and rice husks and lower copper concentrations in grains (Zheng et al., 2012). HvHMA1 in Hordeum vulgare might be involved in mobilizing copper from the aleurone cells during grain filling. The down-regulation of HvHMA1 by RNA interference significantly increased the $\mathrm{Cu}$ content in grains (Mikkelsen et al., 2012).

\section{Progress}

Copper contamination control is a worldwide problem. Cultivation of copper-tolerant plants is one of the methods to alleviate copper contaminated soil. Planting crops in agricultural land with slight copper contamination should pay attention to the potential threat of food safety. The research on plant copper transporters, especially the understanding of their copper distribution mechanism in different parts, can provide scientific theoretical basis and help to establish efficient breeding mechanism and reasonable planting measures. Previous studies have used mutants and overexpression to clarify the physiological functions of some copper transporters, which proved that copper transporters transport copper to specific target organs. Nevertheless, further research is needed to deepen understanding of copper transporters. The following aspects can be carried out. Firstly, the biological characteristics of copper transporters including transporter substrates, expression patterns, and functional sites can be further clarified. Secondly, clarify the functional division of copper transporters and the synergistic overlap 
redundancy relationship. Thirdly, clarify the regulatory effect of transcription factors on copper transporters. It is worth noting that copper transport is inseparable from copper chaperone proteins in plants, and transporters such as $\mathrm{ABC}$ and MATE may also be involved in copper transport. $\mathrm{Cu}$ interacts with other mineral elements, which may seriously affect the copper homeostasis of plants. Referring to the research results of copper transporters in model plants, the mechanism of copper detoxification and tolerance of crop copper transporters was studied by broadening plant research types, making full use of mutant analysis, heterologous expression and omics, and the suitable varieties were screened by copper transporters as indicators. On the basis of in-depth understanding of the mechanism of copper transporters, the use of genetic engineering methods, such as the use of tissue-specific promoters, to achieve the expression of copper transporters in specific parts, but also can inhibit gene expression or gene editing, so as to improve specific traits, change the copper status of plants, block the transfer and accumulation of copper to edible parts, cultivate new crops with high copper tolerance and food safety, which has important application value for the improvement of copper-contaminated farmland.

\section{Authors' contributions}

SYY carried out the study. ZJY participated in the design of the manuscript. GDL conceived of the project, directed the writing and revising of the paper. All authors read and approved the final manuscript.

\section{Acknowledgments}

This study was supported by Major National Special Project for Breeding New Genetically Modified Biological Varieties (No.2016ZX08004-002), National Key R \& D Program (2017YFD0101303), Youth Reserve Talents Project of Harbin Science and Technology Bureau (2017RAQXJ048), College Students' Innovation and Entrepreneurship Project.

\section{Reference}

Amparo S., Sharon P., Khan M.A., Carrió-Seguí À., Mendoza-Cózatl D.G., Peñarrubia L., and Gassmann W., 2018, Copper uptake mechanism of Arabidopsis thaliana high-affinity COPT transporters, Protoplasma, 256(1): 161-170

https://doi.org/10.1007/s00709-018-1286-1

PMid:30043153

Andrés-Bordería A., Andrés F., Garcia-Molina A., Perea-García A., Domingo C., Puig S., and Peñarrubia L., 2017, Copper and ectopic expression of the Arabidopsis transport protein COPT1 alter iron homeostasis in rice (Oryza sativa L.), Plant Mol Biol, 95(1-2): 1-16 https://doi.org/10.1007/s11103-017-0622-8 PMid:28631167

Andrés-Colás N., Perea-García A., Puig S., and Peñarrubia L., 2010, Deregulated copper transport affects arabidopsis development especially in the absence of environmental cycles, Plant Physiol, 153(10): 170-184

https://doi.org/10.1104/pp.110.153676 PMid:20335405 PMCid:PMC2862424

Araki R., Murata J., and Murata Y., 2011, A novel barley yellow stripe 1-like transporter (HvYSL2) localized to the root endodermis transports metal-phytosiderophore complexes, Plant Cell Physiol, 52(11): 1931-1940 https://doi.org/10.1093/pcp/pcr126 PMid:21937676

Ayari F., Hamdi H., Jedidi N., Gharbi N., and Kossai R., 2010, Heavy metal distribution in soil and plant in municipal solid waste compost amended plots, International journal of Environmental Science and Technology, 7(3): 465-472 https://doi.org/10.1007/BF03326156

Bernal M., Testillano P.S., Alfonso M., Del Carmen Risueño M., Picorel R., and Yruela I., 2007, Identification and subcellular localization of the soybean copper P1B-ATPase GmHMA8 transporter, J Stuct Biol, 158(1): 46-58 https://doi.org/10.1016/j.jsb.2006.10.016 PMid:17169574

Billard V., Ourry A., Maillard A., Garnica M., Coquet L., Jouenne T., Cruz F., Garcia-Mina J.M., and Yvin J.C., 2014, Etienne p.copper-deficiency in brassica napus induces copper remobilization, molybdenum accumulation and modification of the expression of chloroplastic proteins, Public Library of Science One, 9(10): e109889 https://doi.org/10.1371/journal.pone.0109889 PMid:25333918 PMCid:PMC4198169

Boutigny S., Sautron E., Finazzi G., Rivasseau C., Frelet-Barrand A., Pilon M., Rolland N., and Seigneurin-Berny D., 2014, HMA1 and PAA1, two chloroplast-envelope PIB-ATPases, play distinct roles in chloroplast copper homeostasis, J Exp Bot, 65(6): 1529-1540 https://doi.org/10.1093/jxb/eru020 PMid:24510941 
Carrio-Segui A., Garcia-Molina A., Sanz A., and Peñarrubia L., 2015, Defective copper transport in the copt5 mutant affects cadmium tolerance, Plant Cell Physiol, 56(3): 442-454

https://doi.org/10.1093/pcp/pcu180

PMid:25432970

Catty P., Boutigny S., Miras R., Joyard J., Rolland N., and Seigneurin-Berny D., 2011, Biochemical characterization of AtHMA6/PAA1, a chloroplast envelope Cu(I)-ATPase, J Biol Chem, 286(42): 36188-36197

https://doi.org/10.1074/jbc.M111.241034

PMid:21878617 PMCid:PMC3196147

Cevher-Keskin B., Yıldızhan Y., Yüksel B., Dalyan E., and Memon A.R., 2018, Characterization of differentially expressed genes to Cu stress in Brassica nigra by Arabidopsis genome arrays, Environmental science and pollution research international, 26(1): 299-311

https://doi.org/10.1007/s11356-018-3577-7

PMid:30397750

Chen M.H., Liu D.L., Zhang W.H., Ma J.J., and Zhao G.Q., 2017, Evaluation on copper enrichment effect of perennial ryegrasses in copper-contaminated soil, Caoyuan Yu Caoping (Grassland and Turf), 37(6): 78-83

Chen Y.F., 2002, Localization of the ethylene receptor ETR1 to the endoplasmic reticulum of arabidopsis, J Biol Chem, 277(22): 19861-19866 https://doi.org/10.1074/jbc.M201286200 PMid:11916973

Dai J., Wang N., Xiong H., Qiu W., Nakanishi H., Kobayashi T., Nishizawa N.K., and Zuo Y., 2018, The yellow stripe-like (YSL) gene functions in internal copper transport in peanut, Genes, 9(12): 635

https://doi.org/10.3390/genes9120635

PMid:30558234 PMCid:PMC6316571

Deng F., Yamaji N., Xia J., and Ma J.F., 2013, A member of the heavy metal p-type atpase OsHMA5 is involved in xylem loading of copper in rice, Plant Physiol, 163(3): 1353-1362

https://doi.org/10.1104/pp.113.226225

PMid:24064929 PMCid:PMC3813655

Desjardins D., Pitre F.E., Nissim W.G., and Labrecque M., 2016, Differential uptake of silver, copper and zinc suggests complementary species-specific phytoextraction potential, Int J Phytoremediation, 18(6): 598-604

https://doi.org/10.1080/15226514.2015.1086296

PMid:26361089

Didonato R.J., Roberts L.A., Sanderson T., Eisley R.B., and Walker E.L., 2004, Arabidopsis yellow stripe-like2 (YSL2): A metal-regulated gene encoding a plasma membrane transporter of nicotianamine-metal complexes, Plant Journal, 39(3): 403-414

https://doi.org/10.1111/j.1365-313X.2004.02128.x

PMid: 15255869

Dumay Q.C., Debut A.J., Mansour N.M., and Saier M.H.J., 2006, The copper transporter (Ctr) family of cu uptake systems, J Mol Microbiol Biotechnol, 11(1-2): 10-19

https://doi.org/10.1159/000092815

PMid: 16825786

Garcia-Molina A., Andres-Colas N., Perea-Garcia A., Neumann U., Dodani S.C., Huijser P., Peñarrubia L., and Puig S., 2013, The arabidopsis COPT6 transport protein functions in copper distribution under copper-deficient conditions, Plant Cell Physiol, 54(8): 1378-1390

https://doi.org/10.1093/pcp/pct088

PMid:23766354

Gayomba S.R., Jung H.I., Yan J., Danku J., Rutzke M.A., Bernal M., Krämer U., Kochian L.V., Salt D.E., and Vatamaniuk O.K., 2013, The CTR/COPT-dependent copper uptake and SPL7-dependent copper deficiency responses are required for basal cadmium tolerance in A. thaliana, Metallomics, 5(9): 1262-1275

https://doi.org/10.1039/c3mt00111c

PMid:23835944

Gong Q., Wang L., Dai T.W., Kang Q., Zhou J.Y., and Li Z.H., 2019, Effects of copper treatment on mineral nutrient absorption and cell ultrastructure of spinach seedlings, Yingyong Shengtai Xuebao (Chinese Journal of Applied Ecology), 30(3): 941-950

Hladun K.R., Parker D.R., and Trumble J.T., 2015, Cadmium, copper, and lead accumulation and bioconcentration in the vegetative and reproductive organs of raphanus sativus: implications for plant performance and pollination, J Chem Ecol, 41(4): 386-395 https://doi.org/10.1007/s10886-015-0569-7 PMid:25845355

Huang G., Rizwan M.S., Ren C., Guo G.G., Fu Q.L., Zhu J., and Hu H.Q., 2016, Influence of phosphorous fertilization on copper phytoextraction and antioxidant defenses in castor bean (Ricinus communis L.), Environmental Science and Pollution Research International, 25(1): 1-9 https://doi.org/10.1007/s11356-016-8132-9

PMid:27882491 
Jung H.I., Gayomba S.R., Rutzke M.A., Craft E., Kochian L.V., and Vatamaniuk O.K., 2012, COPT6 is a plasma membrane transporter that functions in copper homeostasis in Arabidopsis and is a novel target of SQUAMOSA promoter-binding protein-like 7, J Biol Chem, 287(40): 33252-33267 https://doi.org/10.1074/jbc.M112.397810 PMid:22865877 PMCid:PMC3460430

Kacálková L., Tlustoš P., and Száková J., 2009, Phytoextraction of cadmium, copper, zinc and mercury by selected plants, Plant Soil and Environment, 55(7): 295-304 https://doi.org/10.17221/100/2009-PSE

Khurana N., Singh M.V., and Chatterjee C., 2006, Copper stress alters physiology and deteriorates seed quality of rapeseed, J Plant Nut, 29(1): 93-101 https://doi.org/10.1080/01904160500416489

Klaumann S., Nickolaus S.D., Fürst S.H., Starck S., Schneider S., Ekkehard Neuhaus H., and Trentmann O., 2011, The tonoplast copper transporter COPT5 acts as an exporter and is required for interorgan allocation of copper in Arabidopsis thaliana, New Phytologist, 192(2): 393-404 https://doi.org/10.1111/j.1469-8137.2011.03798.x PMid:21692805

Kobayashi Y., Kuroda K., Kimura K., Southron-Francis J.L., Furuzawa A., Kimura K., Iuchi S., Kobayashi M., Taylor G.J., and Koyama H., 2008, Amino acid polymorphisms in strictly conserved domains of a P-type ATPase HMA5 are involved in the mechanism of copper tolerance variation in Arabidopsis, Plant Physiol, 148(2): 969-980 https://doi.org/10.1104/pp.108.119933 PMid:18701674 PMCid:PMC2556842

Kubota J., Welch R.M., and Campen D.R.V., 1992, Partitioning of cadmium, copper, lead and zinc amongst above-ground parts of seed and grain crops grown in selected locations in the USA, Environ Geochem Health, 14(3): 91-100 https://doi.org/10.1007/BF01784020 PMid:24197961

Kulhari A., Sheorayan A., Bajar S., Sarkar S., Kalia R.K., and Chaudhury A., 2013, Investigation of heavy metals in frequently utilized medicinal plants collected from environmentally diverse locations of north western India, Springer Plus, 2(1): 676-685 https://doi.org/10.1186/2193-1801-2-676 PMid:24386622 PMCid:PMC3877414

Lee S., Kim Y.Y., Lee Y., and An G., 2007, Rice P1B-type heavy-metal ATPase, OsHMA9, Is a metal efflux protein, Plant Physiol, 145(3): 831-842 https://doi.org/10.1104/pp.107.102236 PMid:17827266 PMCid:PMC2048805

Leng X.P., Jia H.F., Sun X., Shang guan L.F., Mu Q., Wang B.J., and Fanga J.G., 2015, Comparative transcriptome analysis of grapevine in response to copper stress, Sci Rep, 5: 17749 https://doi.org/10.1038/srep17749 PMid:26673527 PMCid:PMC4682189

Li D.S., 2019, Heavy metal pollution and risk assessment of vegetables in farmland around smelting area, Henan Kexue (Henan Science), 37(04): 81-86

Li H.X., Fan R.C., Li L.B.,Wei B., Li G.L., Gu L.Q., Wang X.P., and Zhang X.Q., 2013, Identification and characterization of a novel copper transporter gene family TaCT1 in common wheat, Plant Cell Environ, 37(7): 1561-1573

https://doi.org/10.1111/pce.12263 PMid:24372025

Liu X.S., Feng S.J., Zhang B.Q., Wang M.Q., and Yang Z.M., 2019, OsZIP1 functions as a metal efflux transporter limiting excess zinc, copper and cadmium accumulation in rice, BMC Plant Biology, 19(1): 283-299 https://doi.org/10.1186/s12870-019-1899-3 PMid:31248369 PMCid:PMC6598308

Mahmud S., Hassan M.M., Moniruzzaman M., Biswas N., Rahman M.M., and Haque M.E., 2013, Study on the accumulation of copper from soil by shoots and roots of some selective plant species, Inter J Biosci, 3: 68-75 https://doi.org/10.12692/ijb/3.6.68-75

Martins V., Bassil E., Hanana M., Blumwald E., and Gerós H., 2014, Copper homeostasis in grapevine: functional characterization of the Vitis vinifera copper transporters, Planta, 240(1): 91-101 https://doi.org/10.1007/s00425-014-2067-5 PMid:24691572

Mikkelsen M.D., Pedas P., Schiller M., Vincze E., Mills R.F., Borg S., Møller A., Schjoerring J.K., Williams L.E., Baekgaard L., Holm P.B., and Palmgren M.G., 2012, Barley HvHMA1 is a heavy metal pump involved in mobilizing organellar zn and cu and plays a role in metal loading into grains, PLOS One, 7(11): e49027

https://doi.org/10.1371/journal.pone.0049027 PMid:23155447 PMCid:PMC3498361 
Mills R.F., Francini A., Rocha P.S.C.F.D., Baccarini P.J., Aylett M., Krijger G.C., and Williams L.E., 2005, The plant P1B-type ATPase AtHMA4 transports Zn and $\mathrm{Cd}$ and plays a role in detoxification of transition metals supplied at elevated levels, FEBS Letters, 579(3): 783-791

https://doi.org/10.1016/j.febslet.2004.12.040

PMid: 15670847

Ministry of environmental protection ministry of land and resources, 2014, National Soil Pollution Status Survey Bulletin, Huanjing Jiaoyu (Environmental education), (06): 8-10

Motior M.R., Tan P.J., Faruq G., Sofian A.M., Rosli H., and Boyce A.N., 2013, Use of amaranth (amaranthus paniculatus) and Indian mustard (brassica juncea) for phytoextraction of lead and copper from contaminated soil, Inter Journal of Agriculture Biology, 15(5): 903-908

Muhammad A., Shafaqat A., Muhammad R., Muhammad I., Farhat A., Mujahid F., Muhammad Z.R., Muhammad K.I., and Saima A.B., 2015, The effect of excess copper on growth and physiology of important food crops: a review, Environmental Science and Pollution Research, 22(11): 8148-8162

Patterson S.L., LaMonte M.P., Mikdashi J.A., Haines S.T., and Hursting M.J., 2006, The arabidopsis heavy metal P-type ATPase HMA5 interacts with metallochaperones and functions in copper detoxification of roots, Plant J, 45(2): 225-236

https://doi.org/10.1111/j.1365-313X.2005.02601.x

PMid: 16367966

Printz B., Guerriero G., Sergeant K., Audinot J.N., Guignard C., Renaut J., Lutts S., and Hausman J.F., 2013, Combining-Omics to unravel the impact of copper nutritionon alfalfa (medicago sativa) stem metabolism, Plant Cell Physiol, 57(2): 407-422

https://doi.org/10.1093/pcp/pcw001 PMid:26865661 PMCid:PMC4771972

Rahman M.M., Azirun S.M., and Boyce A.N., 2013, Enhanced accumulation of copper and lead in Amaranth (Amaranthus paniculatus), Indian Mustard (Brassica juncea) and sunflower (Helianthus annuus), PLOS One, 8(5): e62941

https://doi.org/10.1371/journal.pone.0062941

PMid:23667546 PMCid:PMC3648544

Reddy M.R., Lameck D., and Rezania M.E., 1989, Uptake and distribution of copper and zinc by soybean and corn from soil treated with sewage sludge, Plant and Soil, 113(2): 271-274 https://doi.org/10.1007/BF02280191

Rehman M., Maqbool Z., Peng D.X., and Liu L.J., 2019, Morpho-physiological traits, antioxidant capacity and phytoextraction of copper by ramie (Boehmeria nivea L.) grown as fodder in copper-contaminated soil, Environmental Science and Pollution Research, 26(6): 5851-5861 https://doi.org/10.1007/s11356-018-4015-6 PMid:30613880

Sancenón V., Puig S., Mateuandrés I., Dorcey E., Thiele D.J., Lola., and Peñarrubia L., 2004, The arabidopsis copper transporter COPT1 functions in root elongation and pollen development, J Biol Chem, 279(15): 15348-15355 https://doi.org/10.1074/jbc.M313321200

PMid: 14726516

Senovilla M., Castro-Rodríguez R., Abreu I., Escudero V., Kryvoruchko I., Udvardi M.K., Imperial J., and González-Guerrero M., 2018, Medicago truncatular, copper transporter 1 (MtCOPT1) delivers copper for symbiotic nitrogen fixation, New Phytologist, 218(2): 696-709

https://doi.org/10.1111/nph.14992

PMid:29349810

Si J.Y., Wang X.L., Zhao H.T., Zhai F.Q., Hua J.M., and Feng K., 2007, Effects of different copper levels on growth, copper accumulation and nutrient uptake of rice seedlings, Nongye Huanjing Kexue Xuebao (Journal of Agro-Environment Science), 26(4): 1312-1315

Si J.Y., Zhao H.T., Wang X.L., Yao C.Y., Deng G.F., Feng K., 2008, Effects of different copper levels on subcellular distribution and chemical forms of copper in maize cells, Nongye Huanjing Kexue Xuebao (Journal of Agro-Environment Science), 27(2): 452-456

Singh S., Korripally P., Vancheeswaran R., and Eapen S., 2011, Transgenic nicotiana tabacumplants expressing a fungal copper transporter gene show enhanced acquisition of copper, Plant Cell Reports, 30(10): 1929-1938

https://doi.org/10.1007/s00299-011-1101-3

PMid:21671073

Singleton C., and Le Brun N.E., 2007, Atx1-like chaperones and their cognate P-type ATPases: copper-binding and transfer, Biometals, 20(3-4): 275-289 https://doi.org/10.1007/s10534-006-9068-1 PMid:17225061

Stephens B.W., Cook D.R., and Grusak M.A., 2011, Characterization of zinc transport by divalent metal transporters of the ZIP family from the model legume Medicago truncatula, Biometals An International Journal on the Role of Metal Ions in Biology Biochemistry and Medicine, 24(1): 51-58 https://doi.org/10.1007/s10534-010-9373-6 PMid:20862522

Tapken W., Ravet K., and Pilon M., 2012, Plastocyanin controls the stabilization of the thylakoid Cu-transporting P-type ATPase PAA2/HMA8 in response to low copper in arabidopsis, J Biol Chem, 287(22): 18544-18550 https://doi.org/10.1074/jbc.M111.318204

PMid:22493454 PMCid:PMC3365703 
Thounaojam T.C., Panda P., Mazumdar P., Kumar D., Sharma G.D., Sahoo L., and Panda S.K., 2012, Excess copper induced oxidative stress and response of antioxidants in rice, Plant Physiol Biochem, 53: 33-39

https://doi.org/10.1016/j.plaphy.2012.01.006

PMid:22306354

Wan H., Du J., He J., Lyu D., and Li H., 2019, Copper accumulation, subcellular partitioning, and physiological and molecular responses in relation to different copper tolerance in apple rootstocks, Tree Physiol, 39(7): 1215-1234

https://doi.org/10.1093/treephys/tpz042

PMid:30977826

Wang H.L., Du H.M., Li H.Y., Huang Y., Ding J.Z., Liu C., Wang N., Lan H., Zhang S.Z., 2018, Identification and functional characterization of the ZmCOPT copper transporter family in maize, PLOS One, 13(7): e0199081

https://doi.org/10.1371/journal.pone.0199081

PMid:30036360 PMCid:PMC6056030

Wang W.X., Cao C.Y., Cui Z.B., and Xu S.K., 2006, Copper enrichment from contaminated soil by alfalfa and its physiological response, Dongbei Daxue Xuebao (Journal of Northeastern University (Natural Science)), 27(10): 1161-1164

Waters B.M., Chu H.H., Didonato R.J., Roberts L.A., Eisley R.B., Lahner B., Salt D.E., and Walker E.L., 2006, Mutations in arabidopsis yellow stripe-like1 and yellow stripe-like3 reveal their roles in metal ion homeostasis and loading of metal ions in seeds, Plant physiol, 141(4): 1446-1458 https://doi.org/10.1104/pp.106.082586 PMid:16815956 PMCid:PMC1533956

Yeh T.Y., Lin C.L., Lin C.F., and Chen C.C., 2015, Chelator-enhanced phytoextraction of copper and zinc by sunflower, Chinese cabbage, cattails and reeds, Inter Journal of Environmental Science and Technology, 12(1): 327-340 https://doi.org/10.1007/s13762-014-0592-1

Yuan M., Li X., Xiao J., and Wang S., 2011, Molecular and functional analyses of COPT/Ctr-type copper transporter-like gene family in rice, BMC Plant Biology, 11(1): 69-81

https://doi.org/10.1186/1471-2229-11-69

PMid:21510855 PMCid:PMC3103425

Zhang Y.Y., Chen K., Zhao F.J., Sun C.J., Jin C., Shi Y.H., Sun Y.Y., Li Y., Yang M., Jing X.Y., Luo J., and Lian X.M., 2018, OsATX1 interacts with heavy metal P1B-type ATPases and affects copper transport and distribution, Plant Physiol, 178(1): 329-344

https://doi.org/10.1104/pp.18.00425 PMid:30002257 PMCid:PMC6130040

Zheng L., Yamaji N., Yokosho K., and Ma J.F., 2012, YSL16 Is a phloem-localized transporter of the copper-nicotianamine complex that is responsible for copper distribution in rice, Plant Cell, 24(9): 3767-3782

https://doi.org/10.1105/tpc.112.103820

PMid:23012434 PMCid:PMC3480301

Zhu J.F., Li M.H., Xie P.J., and Qiao Y.L., 2018, Phytoremediation of single and combined pollution of Cu and Pb by Medicago sativa, Lolium perenne, and Pennisetum alopecuroides, Zhongguo Shengtai Nongye Xuebao (Chinese Journal of Eco-Agriculture), 26(2): 303-313 